\title{
NOTE
}

\section{Base Composition of Deoxyribonucleic Acid from Nannocystis exedens (Myxobacterales)}

\author{
H. BEHRENS, J. FLOSSDORF, AND H. REICHENBACH \\ Gesellschaft für Biotechnologische Forschung, Mascheroder Weg 1, D-3300 Braunschweig-Stöckheim, \\ Federal Republic of Germany
}

The base composition of the deoxyribonucleic acid of 11 strains of Nannocystis exedens varied between 70 and $72 \mathrm{~mol} \%$ guanine plus cytosine $(\mathrm{G}+\mathrm{C})$. Therefore it falls into the $\mathrm{G}+\mathrm{C}$ range known from other myxobacteria, i.e., 67 to $72 \mathrm{~mol} \%$.

Nannocystis was described some years ago as a new genus of myxobacteria; so far only one species, $N$. exedens, is recognized (9). The bacterium is very common in soil and has been isolated from many different environments all over the world. It is perhaps the most common myxobacterium of all. This paper is intended to supply the still-lacking data on the deoxyribonucleic acid (DNA) base composition of the new organism.

The strains chosen for this investigation were all isolated in our laboratory with the

TABLE 1. Base composition of DNA from Nannocystis exedens and other myxobacteria

\begin{tabular}{|c|c|c|c|c|c|c|}
\hline Strain & Origin of strain & $\begin{array}{c}\text { Time of isola- } \\
\text { tion }\end{array}$ & $\begin{array}{c}T_{m}{ }^{a}\left({ }^{\circ} \mathrm{C}\right) \\
\text { (in degrees) }\end{array}$ & $\begin{array}{l}\text { Mol\%G }+ \\
\mathrm{C} \text { from } T_{m}\end{array}$ & $\begin{array}{l}\text { Buoy- } \\
\text { ant } \\
\text { density } \\
\left(\mathrm{g} / \mathrm{cm}^{3}\right)\end{array}$ & $\begin{array}{l}\text { Mol\%G+ } \\
\mathrm{C} \text { from } \\
\text { buoyant } \\
\text { density }\end{array}$ \\
\hline $\begin{array}{l}\text { Nannocystis exedens } \\
\text { Na e } 1^{b}\end{array}$ & Desert soil, Arizona & Oct. 1968 & 94.86 & 71.5 & 1.7298 & 70.9 \\
\hline$N$. exedens $\mathrm{Na} \mathrm{e} 3$ & Field soil, Nebraska & Feb. 1969 & 94.74 & 71.2 & 1.7293 & 70.3 \\
\hline$N$. exedens $\mathrm{Na}$ e7 & $\begin{array}{l}\text { Soil from secondary jun- } \\
\text { gle, American Samoa }\end{array}$ & Dec. 1966 & 95.05 & 72.0 & 1.7297 & 70.8 \\
\hline$N$. exedens $\mathrm{Na}$ el0 & $\begin{array}{l}\text { Field soil, Kaiserstuhl } \\
\text { Mountains, Germany }\end{array}$ & Sept. 1969 & 94.88 & 71.6 & 1.7297 & 70.7 \\
\hline$N$. exedens $\mathrm{Na}$ el4 & $\begin{array}{l}\text { Forest soil, Kaiserstuhl } \\
\text { Mountains, Germany }\end{array}$ & Sept. 1969 & 94.47 & 70.6 & 1.7290 & 70.0 \\
\hline$N$. exedens $\mathrm{Na}$ e 15 & $\begin{array}{l}\text { Grassland soil, Kaiser- } \\
\text { stuhl Mountains, Ger- } \\
\text { many }\end{array}$ & Oct. 1969 & 94.56 & 70.8 & 1.7287 & 69.7 \\
\hline N. exedens $\mathrm{Na}$ e $15^{c}$ & & & 94.56 & 70.8 & 1.7288 & 69.8 \\
\hline$N$. exedens $\mathrm{Na}$ e $15^{t}$ & & & 94.59 & 70.9 & 1.7291 & 70.1 \\
\hline$N$. exedens $\mathrm{Na}$ e16 & $\begin{array}{l}\text { Grassland soil, Kaiser- } \\
\text { stuhl Mountains, Ger- } \\
\text { many }\end{array}$ & Oct. 1969 & 94.54 & 70.8 & 1.7286 & 69.5 \\
\hline N. exedens Na el7 & $\begin{array}{l}\text { Grassland soil, Kaiser- } \\
\text { stuhl Mountains, Ger- } \\
\text { many }\end{array}$ & Oct. 1969 & 94.56 & 70.8 & 1.7290 & 70.0 \\
\hline$N$. exedens $\mathrm{Na} 167^{\circ}$ & $\begin{array}{l}\text { Garden soil, Bangkok, } \\
\text { Thailand }\end{array}$ & June 1970 & 95.09 & 72.1 & 1.7297 & 70.7 \\
\hline$N$. exedens $\mathrm{Na} 283^{c}$ & $\begin{array}{l}\text { Garden soil, Chiang } \\
\text { Mai, Thailand }\end{array}$ & Sept. 1971 & 94.69 & 71.1 & 1.7296 & 70.7 \\
\hline$N$. exedens $\mathrm{Na} 290^{\circ}$ & $\begin{array}{l}\text { Garden soil, Chiang } \\
\text { Mai, Thailand }\end{array}$ & Sept. 1971 & 94.79 & 71.4 & 1.7297 & 70.8 \\
\hline Myxococcus fulvus $\mathrm{Mx}$ f16- & $\begin{array}{l}\text { Soil from Borobudur, } \\
\text { Java }\end{array}$ & March 1971 & 94.37 & 70.4 & 1.7285 & 69.5 \\
\hline $\begin{array}{l}\text { Myxococcus xanthus } \mathrm{Mx} \\
\text { NM }\end{array}$ & $\begin{array}{l}\text { From R. P. Burchard } \\
\text { Baltimore, non-motile } \\
\text { mutant }\end{array}$ & & 94.07 & 69.7 & 1.7269 & 67.8 \\
\hline $\begin{array}{l}\text { Stigmatella aurantiaca } \\
\text { Sg a1 }\end{array}$ & $\begin{array}{l}\text { Rotten wood, Minneapo- } \\
\text { lis, Minn. }\end{array}$ & Sept. 1966 & 92.78 & 66.7 & 1.7261 & 66.9 \\
\hline
\end{tabular}

${ }^{a}$ Data corrected for $0.1 \mathrm{M}\left[\mathrm{Na}^{+}\right]$.

$b$ Type strain.

c Two different determinations of the same DNA preparation.

${ }^{d}$ From a separate DNA preparation.

- Organisms which by their cytology and growth pattern were indistinguishable from $N$. exedens but could not be classified unequivocally because fruiting bodies were not obtained. 
exception of strains $\mathrm{Na}$ e7 and $\mathrm{Sg}$ a1 which were isolated in the laboratory of Martin Dworkin in Minneapolis, Minn., and strain Mx NM which was kindly supplied by Robert P. 'Burchard, Baltimore, Md. Strain $\mathrm{Na}$ e1 is the type strain of $N$. exedens; it is deposited at the ATCC (American Type Culture Collection, Rockville, Md.) (number 25963), and at the DSM (German Collection of Microorganisms, Göttingen, Federal Republic of Germany; number DSM 71). Also, strain $\mathrm{Na}$ e17 is at the ATCC (number 25965). All stock cultures were kept on vy/2agar: baker's yeast $(0.5 \%$; fresh weight of yeast cake), cyanocobalamine $(0.5 \mu \mathrm{g} / \mathrm{ml}), \mathrm{CaCl}_{2}$ (anhydrous; $0.1 \%)$, agar $(1.5 \%)(\mathrm{pH} 7.2$ ), autoclaved at $125^{\circ} \mathrm{C}$ for $30 \mathrm{~min}$. For DNA preparation $N$. exedens was grown in MD1 liquid medium: Casitone (Difco; $0.3 \%$ ), $\mathrm{CaCl}_{2}$ (anhydrous; $0.05 \%$ ), $\mathrm{MgSO}_{4}$ (anhydrous; $0.1 \%$ ), trace elements $(0.5 \mathrm{ml}$ of stock solution per $100 \mathrm{ml}$ of medium) (trace element mixture as given in reference 2). Batches of $100 \mathrm{ml}$ of MD1 liquid medium in $500 \mathrm{ml}$ Erlenmeyer flasks were shaken with $160 \mathrm{cpm}$ at $30^{\circ} \mathrm{C}$ with a stroke of 5 $\mathrm{cm}$. The bacteria grew in the form of brightly colored minute flakes.

The other myxobacteria were grown in Casitone liquid medium: Casitone (1\%), $\mathrm{MgSO}_{4}$ (anhydrous; $0.1 \%$ ), $\mathrm{pH} 6.8$ unadjusted. Culture conditions were as above. These organisms formed homogeneous cell suspensions.

DNA was isolated by the method of Marmur (7) with some modifications. (i) Harvested cells were not washed before treatment with sodium dodecyl sulfate, because part of the DNA was already released during washing. (ii) The deproteinized precipitated DNA was dissolved in $1 / 10$ strength tris(hydroxymethyl)aminomethane (Tris)-hydrochloride- $\mathrm{Na}^{+}$buffer which was brought then to full strength $(50 \mathrm{mM}$ Tris-hydrochloride buffer, $\mathrm{pH} 7.65+10 \mathrm{mM} \mathrm{NaCl}$ ). The dissolved DNA was treated with $50 \mu \mathrm{g}$ of ribonuclease (RNase) A per $\mathrm{ml}$ (Boehringer, Mannheim, Germany) for $45 \mathrm{~min}$ at $37^{\circ} \mathrm{C}$. This was followed by addition of ethylenediaminetetraacetic acid $(10 \mathrm{mM})$ and treatment with 2 $\mu \mathrm{g}$ of RNase $\mathrm{T}_{1}$ per $\mathrm{ml}$ (Boehringer) for $45 \mathrm{~min}$ at $37^{\circ} \mathrm{C}$. Both RNases were heated before use for $15 \mathrm{~min}$ at $80^{\circ} \mathrm{C}$ to destroy any possible deoxyribonuclease activity. (iii) After RNase treatment, $0.5 \%$ sodium dodecyl sulfate and $25 \mu \mathrm{g}$ of proteinase $\mathrm{K}$ per $\mathrm{ml}$ (Boehringer) were added. The mixture was kept at $37^{\circ} \mathrm{C}$ overnight and then deproteinized twice (7).

The guanine plus cytosine $(\mathrm{G}+\mathrm{C})$ content was determined in two ways. (i) From the "melting point" (8): Melting curves were measured with a Gilford model 250 spectrophotome- ter equipped with a thermoprogramer. Temperature increase was 0.5 degrees per min. DNA was dissolved at a concentration of 20 to $30 \mu \mathrm{g} /$ $\mathrm{ml}$ in sodium phosphate buffer $\left(\mathrm{pH} \mathrm{7.0,}\left[\mathrm{Na}^{+}\right]\right.$ $0.1 \mathrm{M}$ ). (ii) From the buoyant density (6): The buoyant density, $\rho$, was determined in a $\mathrm{CsCl}$ gradient on a Beckman model $\mathrm{E}$ analytical ultracentrifuge after $48 \mathrm{~h}$ at $44,000 \mathrm{rpm}$ at $25^{\circ} \mathrm{C}$. Escherichia coli DNA $\left(\rho=1.71 \mathrm{~g} / \mathrm{cm}^{3}\right)$ served as a reference. The guanine plus cytosine $(\mathrm{G}+\mathrm{C})$ content was calculated with the DeLey (1) formula: $\mathrm{G}+\mathrm{C}=1038.47(\rho-1.6616)$. Usually DNA was prepared from each strain only once. With strain $\mathrm{Na}$ e15, however, two separate experiments were performed. As can be seen from Table 1 results were nearly identical.

As shown in Table 1, the investigated strains of $N$. exedens varied little in the $\mathrm{G}+\mathrm{C}$ content of their DNA. Furthermore, the 69 to $72 \mathrm{~mol} \%$ $\mathrm{G}+\mathrm{C}$ found with different Nannocystis strains fell into the narrow range of 67 to $72 \mathrm{~mol} \% \mathrm{G}+\mathrm{C}$ known for other myxobacteria (3-5).

We thankfully appreciate the expert technical assistance of $\mathrm{H}$. Schillig at the ultracentrifuge.

\section{REPRINT REQUESTS}

Address reprint requests to: Dr. H. Reichenbach, Gesellschaft für Biotechnologische Forschung, Mascheroder Weg 1, D-3300 Braunschweig-Stöckheim, Federal Republic of Germany.

\section{LITERATURE CITED}

1. Deley, J. 1970. Reexamination of the association between melting point, buoyant density, and chemical base composition of deoxyribonucleic acid. J. Bacteriol. 101:738-754.

2. Drews, G. 1974. Mikrobiologisches Praktikum, 2nd. ed., p. 6. Springer, Berlin.

3. Johnson, J. L., and E. J. Ordal. 1968. Deoxyribonucleic acid homology in bacterial taxonomy: effect of incubation temperature on reaction specificity. J. Bacteriol. 95:893-900.

4. McCurdy, H. D., and S. Wolf. 1967. Deoxyribonucleic acid base composition of fruiting Myxobacterales. Can. J. Microbiol. 13:1707-1708.

5. Mandel, M., and E. R. Leadbetter. 1965. Deoxyribonucleic acid base composition of myxobacteria. J. Bacteriol. 90:1795-1796.

6. Mandel, M., C. L. Schildkraut, and J. Marmur. 1968. Use of $\mathrm{CsCl}$ density gradient analysis for determining the guanine plus cytosine content of DNA. In L. Grossman and K. Moldave (ed.), Methods in enzymology, vol. 12B, p. 184-195. Academic Press Inc., New York.

7. Marmur, J. 1961. A procedure for the isolation of deoxyribonucleic acid from micro-organisms. J. Mol. Biol. 3:208-218.

8. Owen, R. J., L. R. Hill, and S. P. Lapage. 1969. Determination of DNA base composition from melting profiles in dilute buffers. Biopolymers 7:503-516.

9. Reichenbach, H. 1970. Nannocvstis exedens gen. nov., spec. nov., a new myxobacterium of the family Sorangiaceae. Arch. Microbiol. 70:119-138. 